\title{
Høy dødelighet blant kvinnelige alkoholmisbrukere
}

\author{
Vi vet lite om prognosen på lang sikt for kvinnelige alkoholmisbrukere. \\ Nå har norske og svenske forskere publisert data med opptil 25 års \\ oppfølgingstid.
}

Studien omfatter 420 kvinner behandlet i det såkalte EWA-programmet (Early Treatment for Women with Alcohol Addiction), som startet i 1981 ved Karolinska Universitetssjukhuset. Bakgrunnen var at pioneren Lena Dahlgren hadde påvist en høyere dødelighet for kvinner med alkoholproblemer sammenliknet med tilsvarende menn, på hele $4-5$ ganger i forhold til kvinner generelt i befolkningen. Dette kunne henge sammen med at kvinnene hadde et enda mer fremskredent problem når de kom til behandling, kanskje pga. manglende adekvate behandlingstilbud.

Kvinnene ble tilbudt to års behandling, rettet mot både alkoholproblemet og psykiatriske lidelser. Kvinnens partner og barn ble også tilbudt hjelp. Bare kvinner som tidligere ikke hadde vært behandlet for alkoholproblemer ble tatt imot. Programmet vakte internasjonal oppsikt og var i sin tid det mest besøkte på Karolinska Universitetssjukhuset - av klinikere og forskere fra hele verden.

-25 år etter at de første kvinnene kom $\mathrm{i}$ behandling har vi gjort en registerstudie av dødeligheten blant 420 av disse (1). Resultatene viser at dødeligheten er lavere i EWA-gruppen enn tidligere grupper av kvinnelige alkoholavhengige: 2,4 ganger høyere enn en paret gruppe fra befolkningen. Men de yngste kvinnene hadde en fire ganger høyere mortalitet, og blant dem som avbrøt behandlingen var dødeligheten hele fem ganger høyere. Som forventet var alkoholrelaterte dødsårsaker signifikant overrepresentert, sier førsteforfatter Brit Haver ved Universitetet i Bergen.

I senere delstudier vil vi fokusere på behandlingseffekt og omkostninger. En randomisert studie av 200 kvinner fra EWA-pro- grammet ble utført i midten av 1980-årene. Halvdelen fikk behandling på EWA-enheten, mens de øvrige fikk behandling på en kjønnsblandet avdeling eller poliklinikk uten noe spesialisert program for kvinner. En 25 års oppfølging av dette materialet er også unikt.

Ettersom kvinnene fra programmet i sosioøkonomisk henseende likner kvinner fra den alminnelige befolkningen, kan resultatene i større grad generaliseres til bredere grupper av kvinnelige alkoholmisbrukere, sier Haver.

\section{Norsk-svensk forskningssamarbeid} Forskergruppen består av professor Brit Haver, som er prosjektleder, og psykolog Rolf Gjestad ved Universitetet i Bergen samt psykolog Staffan Lindberg og psykiater Johan Franck ved Sektionen för beroendeforskning, Karolinska Institutet. Samarbeidet kom i stand ved at Brit Haver var gjesteforsker ved EWA-programmet i 1991-94. Hun gjorde en inngående studie av psykiatrisk komorbiditet blant 120 av kvinnene, og disse inngår i oppfølgingsstudien som nå pågår.

Longitudinelle studier av kvinner behandlet for alkoholproblemer har vært et hovedområde for Brit Havers forskningsinteresse gjennom mer enn 20 år. Rolf Gjestad arbeider med en doktorgradsstudie av EWA-materialet.

\section{Erlend Hem \\ erlend.hem@medisin.uio.no \\ Tidsskriftet \\ Litteratur \\ 1. Haver B, Gjestad R, Lindberg S et al. Mortality risk up to 25 years after initiation of treatment among 420 Swedish women with alcohol addiction. Addic- tion 2009; 104: 413-9.}

\section{Ordforklaringer}

EWA-programmet: Early Treatment for Women with Alcohol Addiction.

Alkoholmisbruk: Fysisk eller psykisk skade med funksjonsnedsettelse som følge av et maladaptivt drikkemønster.

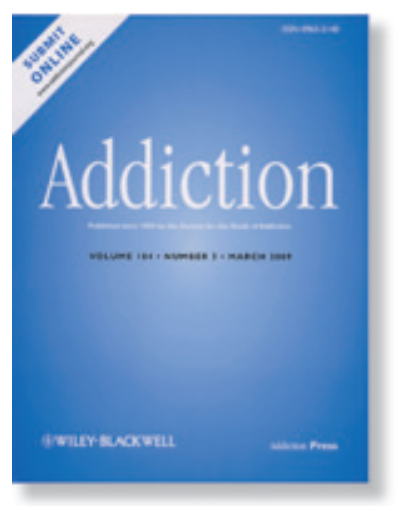

Artikkelen ble publisert i Addiction (www.addictionjournal.org), som er det høyest rangerte tidsskriftet innen forskning på rusmisbruk

\section{Tips oss}

Erdu iferd med å publisere eller har du nylig publisert eller har du nylig publisert Send tips til erlend.hem@medisin.uio.no 